\title{
Comparative investigation of volatile fatty acids, soluble glucides and cellulase enzymes activity in cattle and buffaloes
}

\author{
D Trasnea, M Olteanu, F Sachelarie, G Burlacu, M Nicolae \\ Institute of Biology and Animal Nutrition, 8113, Balotesti, Romania
}

Following a comparative study of the ruminal fermentation in cattle and buffaloes, we present some data on the volatile fatty acids (VFA), readily soluble glucides and cellulase enzymes activity in the rumen.

The experiment used four males of each species, weighing $275 \mathrm{~kg}$ in average, fistulated ruminally and fitted with cannulae. Two diets were used : alfalfa half-silage given ad libitum and alfalfa half-silage supplemented with a concentrate mixture (corn, sunflower meal, peas and a vitamin-mineral premix). The diets were given in two meals at 08.00 and 20.00 hours.

The ruminal liquid was sampled during daytime, ante and postprandially (at 1, 2, 4, 6 and $12 \mathrm{~h}$ ), through the cannulae.
The highest values of the analysed parameters were at 2-4 hours postprandially in both variants and species and are given in the table below. In cattle, the highest VFA concentration was significantly lower than in buffaloes for both diets. The molar proportion of acetic acid was significantly higher in buffaloes and that of butyric acid was significantly higher in cattle.

The highest concentrations of starch and total sugar were not significantly different between species.

For the same diet, the maximal enzymatic activity of $\beta 1.4$ endoglucanase and cellulase didn't differ significantly between the studied species, and the highest enzymatic activity of $\beta 1.4$ cellobiohydrolase $C x$ was significantly lower in buffaloes than in cattle.

\begin{tabular}{|c|c|c|c|c|}
\hline & \multicolumn{2}{|c|}{ Alfalfa half-silage } & \multicolumn{2}{|c|}{$\begin{array}{l}\text { Alfalfa half-silage } \\
+ \text { concentrate }\end{array}$} \\
\hline & Cattle & Buffalo & Cattle & Buffalo \\
\hline Total VFA $(\mathrm{mmol} / \mathrm{l})$ & $142.6^{a}$ & $160.1^{\mathrm{b}}$ & $200.9^{a}$ & $241.3^{\mathrm{b}}$ \\
\hline Acetic acid $(\%)$ & $61.9^{\mathrm{a}}$ & $65.2^{\mathrm{b}}$ & $56.5^{\mathrm{a}}$ & $62.3^{\mathrm{b}}$ \\
\hline Propionic acid (\%) & 14.7 & 15.6 & 15.1 & 13.8 \\
\hline Butyric acid (\%) & $23.4^{a}$ & $19.2^{b}$ & $28.4^{a}$ & $23.9^{b}$ \\
\hline Starch $(\mathrm{mg} / 100 \mathrm{ml})$ & 85.1 & 90.9 & 413.2 & 447.2 \\
\hline Total sugar $(\mathrm{mg} / 100 \mathrm{ml})$ & 50.8 & 53.2 & 249.2 & 243.3 \\
\hline$\beta 1.4$ endoglucanase $C 1$ activity & & & & \\
\hline $\begin{array}{l}\text { ( } \mathrm{mg} \text { glucose } / \mathrm{ml}) \\
\text { B1.4 cellobiohydrolase Cx activity }\end{array}$ & 0.661 & 0.579 & 0.796 & 0.727 \\
\hline (mg glucose $/ \mathrm{ml}$ ) & $0.466^{a}$ & $0.375^{b}$ & $0.412^{a}$ & $0.313^{\mathrm{b}}$ \\
\hline Cellobiase activity (mg glucose/ml) & 0.137 & 0.109 & 0.168 & 0.138 \\
\hline
\end{tabular}

For each diet significant difference $(P \leq 0.05)$ between species is indicated by a different letter. 